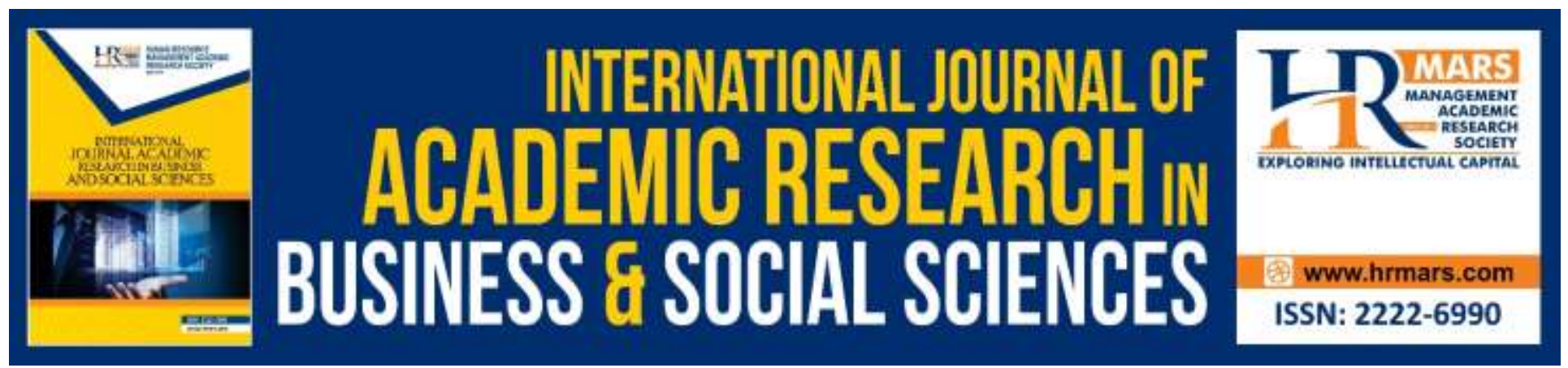

\title{
Workplace Bullying on Employees' Intention to Quit: A Study Among Sales Representatives in One of a Leading Sales and Distribution Company in Sri Lanka
}

\author{
H. Michelle S. V. Silva, P. V. N. N. Senarathna
}

To Link this Article: http://dx.doi.org/10.6007/IJARBSS/v10-i2/6939

DOI:10.6007/IJARBSS/v10-i2/6939

Received: 03 January 2020, Revised: 28 January 2020, Accepted: 02 February 2020

Published Online: 19 February 2020

In-Text Citation: (Silva \& Senarathna, 2020)

To Cite this Article: Silva, H. M. S. V., \& Senarathna, P. V. N. N. (2020). Workplace Bullying on Employees' Intention to Quit: A Study Among Sales Representatives in One of a Leading Sales and Distribution Company in Sri Lanka. International Journal of Academic Research in Business and Social Sciences, 10(2), 412-421.

Copyright: (C) 2020 The Author(s)

Published by Human Resource Management Academic Research Society (www.hrmars.com)

This article is published under the Creative Commons Attribution (CC BY 4.0) license. Anyone may reproduce, distribute, translate and create derivative works of this article (for both commercial and non-commercial purposes), subject to full attribution to the original publication and authors. The full terms of this license may be seen

at: http://creativecommons.org/licences/by/4.0/legalcode

Vol. 10, No. 2, 2020, Pg. 412 - 421

http://hrmars.com/index.php/pages/detail/IJARBSS

JOURNAL HOMEPAGE

Full Terms \& Conditions of access and use can be found at

http://hrmars.com/index.php/pages/detail/publication-ethics 


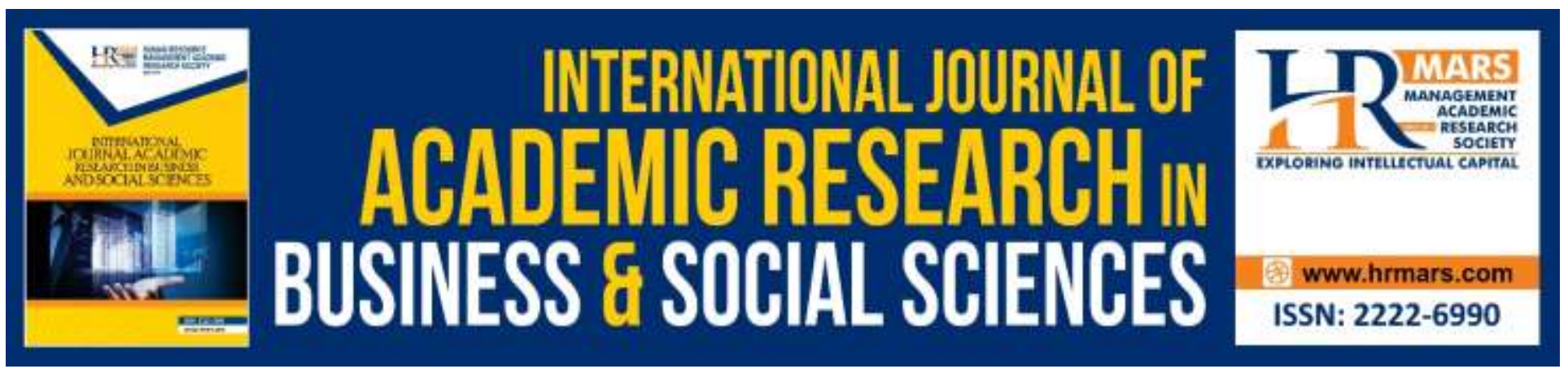

\title{
Workplace Bullying on Employees' Intention to Quit: A Study Among Sales Representatives in One of a Leading Sales and Distribution Company in Sri Lanka
}

\author{
H. Michelle S. V. Silva \\ Senior Lecturer, Department of Human Resource Management, Faculty of Commerce and \\ Management Studies, University of Kelaniya, Sri Lanka \\ Email: michellevindya@kln.ac.lk \\ P. V. N. N. Senarathna \\ Department of Human Resource, Management University of Kelaniya, Sri Lanka \\ Email:n2senarathna@gmail.com
}

\begin{abstract}
This study has investigated the impact of workplace bullying on employee's intention to quit from the position of sales representatives in one of a leading sales and distribution company in Sri Lanka. Further, this study has examined the moderating effect of perceived organizational support on the relationship between above two variables. This study is a quantitative study and carried out by following a deductive approach. Meanwhile, researcher has used sixty three respondents as the sample of the study and sample was selected based on simple random sampling method. Additionally, data was gathered through standard pre- tested questionnaire. The First hypothesis was tested using simple linear regression analysis and It was identified that there was a significance impact from workplace bullying on employee's intention to quit from the position of sales representatives in this company. Afterwards the moderating impact of perceived organizational support on the relationship between workplace bullying and employee's intention to quit was tested and it was concluded that perceived organizational support is no more a moderator in between these two variables. Thus, Hypothesis two was rejected so that these kinds of companies have to pay more attention on diminishing bullying attempts that employees experienced from their superiors and other workers rather than only considering in promoting supportive organization attitudes.
\end{abstract}

Keywords: Workplace Bullying, Perceived Organizational Support, Intention to Quit 
INTERNATIONAL JOURNAL OF ACADEMIC RESEARCH IN BUSINESS AND SOCIAL SCIENCES Vol. 10, No. 2, Feb, 2020, E-ISSN: 2222-6990 @ 2020 HRMARS

\section{Background and Research Problem}

"HRM is the effective and efficient utilization of human resources to achieve goals of the organization" (Opatha, 2012, p.7). Human resource is the most valuable resource in the company because they are rare, unique, valuable and no substitutable which can add competitive advantage to the organization other than human resources (Wright, McMahan, \& Mc Williams, 1994).Thus, Organizations should pay much attention on retaining their skilled workers since they are the backbone of organization's competitive advantage. When organizations are focusing on retaining skilled workers, employee turnover will become an obstacle and a challenge for such retention attempts today. In literature, intention to quit was identified as the direct and stronger originator of turnover (Steel \& Ovalle, 1984,). Therefore, in order to reduce the employee turnover, it is highly important to specify and deal effectively with the turnover intentions of employees.

Mobley's (1977) Model of the Turnover Process explained that the employee evaluates their job when they have decided to quit from their job. Lee and Mitchell (1994) in contrast argue from their 'The unfolding model (1994)' that employee's don't just accidentally assess their job unless there is a situation that gives them a reason to evaluate their current position. The Unfolding Model tags these situations as "shocks" and pronounces them as an event that forces the employee to evaluate their job (Lee \& Mitchell, 1994). Shocks may appear in both negative events, like being bullied and laid off or but they can also be positive events such as, promotions or bonuses. When organizations struggling with employee intention to quit, Workplace bullying has become a core shock experiencing by majority of the employees in the organizations now days. Thus, organizations are now paying high attention towards effective dealing of work place bullying. Moreover, scholars have identified that bullying reduce the organizational performance by effecting the individual performance through both absenteeism and employee turnover (Quine, 1999).

Intention to quit could be known as propensity to withdraw from the work (Hellgren, Sjoberg \& Sverke, 1997). According to Hellgren, (1997), as cited evidence from Hom, Katerberg \& Hulin, 1979) stated that intention to quit is the best predictor for actual turnover. According to Rayner and Cooper (1997, as cited in Djurkovic, McCormack \& Casimir, 2008) it is evident that employees decided to leave their organizations because of they were being bullied. Bullying is exercised through both indirect and direct actions of employees. Few indirect acts of aggression are social segregation, gossiping and rumors and on the other side direct actions are public humiliation, verbal abuse and accusations (Seigne, O'Moore, Smith \& McGuire, 1998).

Therefore, workplace bullying has become a serious issue for the organizations nowadays which later encourage employee to quit from their jobs. According to Lutgen-Sandvik and (Sypher, 2009: Laschinger \& Fida, 2014) "Bullying is 'an organizational, not an individual problem" (p.63). To ensure the permanency of service within an organization, it has been said that it is important for employees to have the obligatory support from their organization.

Eisenberger et al. (1986) declared that 'Employees' perception of the extent to which the organization values their contribution and cares about their well-being is called POS' (p.847). Absence of perceived organizational support made workplace bullying attempts under reported due to the fear of penalty. In spite of numerous theoretical and empirical studies that examine Turnover Intention of employees, fewer studies have attempted to examine the relationship 
INTERNATIONAL JOURNAL OF ACADEMIC RESEARCH IN BUSINESS AND SOCIAL SCIENCES Vol. 10, No. 2, Feb, 2020, E-ISSN: 2222-6990 @ 2020 HRMARS

between Perceived Organizational Support (POS) and intention to quit (Jayasundara, Jayakody, Jayawardana, 2016).

Perceived organizational support (POS) is employee's assumption on how well organization values employee's commitment and extent to which organization attentions about their well-being (Rhoades \& Eisenberger, 2002). When employees feel their organization is value their contributions and pay much attention on him employees feel sense of commitment toward the organization.

Thus, this study intends to analyze whether perceived organizational support (POS) act as a moderator on the relationship between workplace bulling and employee's intention to quit.

In Sri Lankan context, there are limited number of studies conducted regarding workplace bullying and employee's intention to quit organizations. Most Sri Lankan organizations attempt to hinder the information of workplace bulling as it is private and confidential information in the organizations. (Edirisinghe \& De Alwis, 2015).

Additionally, there is no evidence from the sales and distribution sector organizations in Sri Lanka conducted considering these three variables together. Thus, current researcher has selected sales representatives as the potential respondents of the study,. Most of the time they are the set of employees doing their jobs with irrepressible tasks and impractical targets. Thus, they continuously being caught for superior's spontaneous anger. Therefore, current study was carried out considering sales representatives as potential respondents in one of a leading sales and Distribution organization in Sri Lanka

To conduct the current study, researcher has selected a well-established sales and distribution company in Sri Lanka. Moreover, the most popular FMCG Sales and Distribution Company in Sri Lanka is under their management. Thus, this study has considered sales and distribution plant as the population of this study. Furthermore, as they are the largest team of sales representative in Sri Lanka (company Annual report ,2016) this study was able to find more accurate finding relating to sales representatives' intention to quit in Sri Lanka. According to the Sri Lankan Labor Demand Survey (2017), commercial and sales representative's occupation is in the 8th place out of top 20 occupations, which the most number of employees quitted from 2015 to June 2017(p.22) Moreover, sales representative occupation won $6^{\text {th }}$ place out of top 20 occupations, which the most number of male employees quitted from 2015 to June 2017. Within this selected organization, sales representatives dominates the $45.69 \%$, which is the highest turnover percentage among the total turnovers from the period of 1st of January 2018-August $31^{\text {st }}$ of 2018.

According to the above research problem, the research questions are as follows.

\section{Research Questions}

1. What is the impact of workplace bullying on intention to quit from the positions of Sales representatives in one of a leading Sales and Distribution Company in Sri Lanka?

2. Whether perceived organizational support (POS) moderates the relationship between workplace bullying and intention to quit from the positions of sales representatives in one of a leading Sales and Distribution Company in Sri Lanka? 
INTERNATIONAL JOURNAL OF ACADEMIC RESEARCH IN BUSINESS AND SOCIAL SCIENCES Vol. 10, No. 2, Feb, 2020, E-ISSN: 2222-6990 @ 2020 HRMARS

\section{Conceptual Framework and Hypothesis Development}

Based on the literature support current researcher developed the following hypothesis to be tested. H1: There is a significant impact from employee's workplace bullying on intention to quit

H2: POS significantly moderates the relationship between workplace bullying and employee's intention to quit.

\section{Conceptual Framework of the Study}

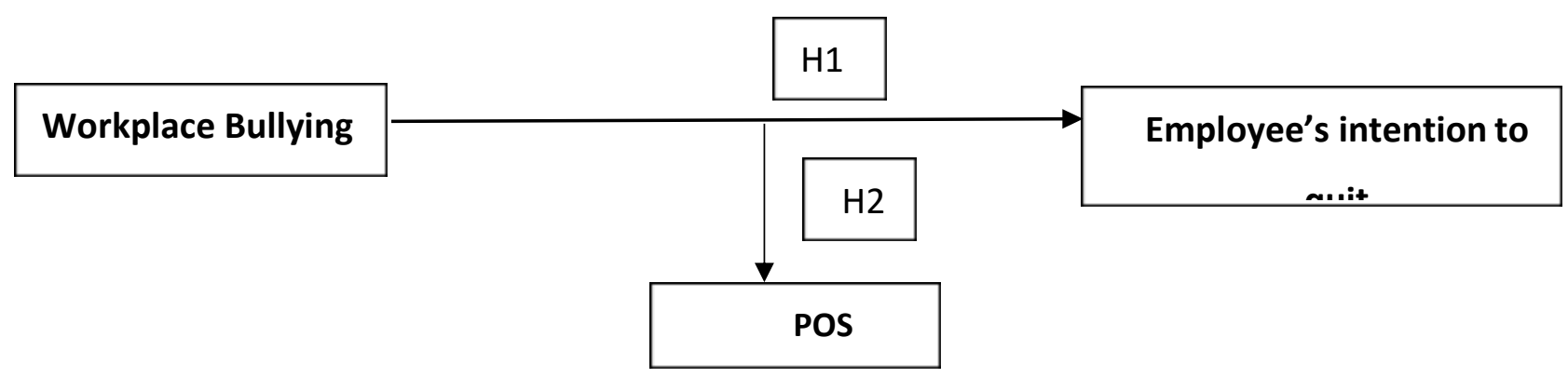

\section{Operationalization of the study}

Intention to quit is known as employee's tendency to withdraw from the existing job (Hellgren, Sjoberg \& Sverke, 1997) in this study. This dependent variable is measured by the scale of Hellgren, Sjoberg \& Sverke, (1996).

Next, Workplace bulling is measured using Negative Acts Questionnaire Revised version (NAQ-R) developed by Einarsen and Hoel (2001). According to Hauge et al., (2009, as cited in Laschinger \& Fida, 2014). The working definition of Workplace bullying is "repeated and prolonged exposure to predominantly psychological mistreatment, directed at a target who is typically teased, badgered and insulted, and who perceives himself or herself as not having the opportunity to retaliate in kind" (p.350). This measurement consists with 22 items and measured through five -point likert scale.

Next, POS is defined as "employee's assumption on how well organization values my dedication and extent to which organization cares about my well-being" (Rhoades \& Eisenberger, 2002). POS was measured using shorter version scale of Eisenberger et al. (1986). This measurement is used Five point Likert scale.

\section{Methodology}

This study is a quantitative study followed a deductive approach.

Population and sample - In current study population was consisted with all the sales representatives working in the selected Sales and Distribution Company in Sri Lanka. According to the company human resource information 2017, the total population of this study would be 322 male employees.

Thus, the potential respondents of this study would be 65 employees which covers $20 \%$ of the total population. Moreover, as the sampling technique Simple random sampling technique was used which provide equal opportunity to every person in the population has used to select potential respondents of the study. 
INTERNATIONAL JOURNAL OF ACADEMIC RESEARCH IN BUSINESS AND SOCIAL SCIENCES Vol. 10, No. 2, Feb, 2020, E-ISSN: 2222-6990 @ 2020 HRMARS

Data Collection -Both primary and secondary sources of data sources were used. Survey questionnaire and focused group interview were also used. As secondary data sources company Human resource information system (HRIS) information from 2015-2018 and exit interview data were used.

Data Collection - Standardized pre-tested questionnaire was used and a pilot study was conducted with randomly selected participants from the population. The effective response rate of this study was $78.75 \%$.

Sample Description - Among the sample respondents 49 (77.8\%) are sales representatives and 14 respondents (22.2\%) are trainee sales representatives. All respondents of this study were male and majority were in the age between 26 -35 years. Out of 63 respondents 30 (48\%) were married. Highest percentage of sales representatives were successfully completed their G.C.E advanced level examination conducting by the Education ministry in Sri Lanka. Among them 11 (17.5\%) persons were obtained their tertiary education qualification from The Sri Lanka Institute of Marketing (SLIM).When analyzing the job seniority of the respondents it is evident that 33 representatives (52.4\%) have worked for this company in between $1-5$ years.

\section{Preliminary Investigation}

Preliminary investigation should be done to ensure whether data set is ready to run the regression.

\section{Descriptive Measures}

The mean value of intention to quit was 3.4921 with standard deviation of 1.01398. In addition the Skewness and kurtosis values were -.656 and .060 respectively. According to Kline (2005, as cited in Harrington, 2008) established a rule of thumb for skew index of absolute value less than 03 and kurtosis value less than 10 are satisfactorily normally distributed. Thus, the variable intention to quit can be concluded as a normal distribution.

Workplace bullying-mean value was 3.3558 and its Standard deviation is 0.99598 . Moreover, Skewness and kurtosis values were -1.188 and 0.667 respectively. Thus, Work place bullying also normally distributed.

Perceived organizational support- mean value of Perceived organizational support is 3.4635 with 0.76860 standard deviation. In addition, Skewness and kurtosis values were -1.26 and 0.117 respectively. Finally POS variable distribution also can be concluded as normal.

Validity - In order to identify the linearity of the two concepts scattered plot diagram was used. With the intention of getting statistically insight idea of the linearity ANOVA table is generated. Thereby, the table indicates deviation of linearity sig value of 0.878 . As the condition of linearity that sig value should be greater than the 0.05 . Therefore, statistically it is proven that independent and dependent variables of the current study were linear.

The content validity of the questionnaire was ensured by the conceptualization and Operationalization of the variables based on literature. 
INTERNATIONAL JOURNAL OF ACADEMIC RESEARCH IN BUSINESS AND SOCIAL SCIENCES Vol. 10, No. 2, Feb, 2020, E-ISSN: 2222-6990 @ 2020 HRMARS

Validity is used to ensure sample adequacy. KMO and Bartlett's test was used to compute the validity of the current study. The KMO and Bartlett's values of intention to quit, Workplace bullying and POS were $0.567,0.865$ and 0.671 respectively. Since all three values were exceeded minimum threshold value 0.5 , it can be concluded that all three variables are validate to run the regression.

Reliability - The coefficient of Cronbach's Alpha of the reliability test for all variables showed the value more than 0.7 . According to that, the questionnaire had a higher degree of reliability Spector (1997). Thus, there is high reliability and validity for questionnaire and therefore, it used to measure degree of work place bullying and degree of Intention to quit.

These Correlation values can be assessed against the criteria provided by Field (2009). Correlation between workplace bulling and intention to quit was 0.743 which indicates the strong positive relationship. Next, the results of the Pearson correlation between workplace bulling and perceived organizational support was -.109 and it was concluded that there is a weak negative relationship between them. Moreover, correlation between intention to quit and Perceived organizational support was -.050 which indicates also a weak negative relationship. Further state that all these three values were significant under 0.05 . Therefore, it was statistically proven that there was a significant relationship between all three variables.

\section{Hypothesis Testing}

6.1 H1: There is a significant impact from employee's workplace bullying on intention to quit.

The standardized coefficient of beta $(\beta)$ value of the equation was .743 which indicates that there is a positive significance impact from workplace bulling on sales representative's intention to leave in one of the leading sales and Distribution Company in Sri Lanka. This $(\beta)$ value is tested when moderator is of perceived organizational support is held constant.

The $(\beta)$ value of the equation, the slope of the regression line was 0.743 is significant at 0.000 which is less than

0.05. This indicates that if we increase workplace bulling by one unit, intention to quit will be increased by 0.743 units.

The Adjusted $\mathrm{R}^{2}$ value was 0.545 . Thus, it can be concluded that $54.5 \%$ of variation in intention to quit can be explained by 'Work place bullying'. Thus, it can be stated that first hypothesis (H1) is accepted and it has significant impact of Workplace bulling on Intention to quit from the positions of the sales representatives in sales and distribution organizations.

\section{Analyzing the Moderator}

Moderator analysis used to analyze whether the original relationship between independent and dependent variable can be moderated by the existence of a third variable. This moderator analysis was done using the steps of Moderator Multiple Regression (MMR) introduced by Baron and Kenny (1986). But, according to the results of current analysis, the significant value would be 0.909 which was exceeded the accepted significance level of 0.05. Therefore, findings stated that POS is not a moderator on the relationship between workplace bulling and employee's intention to quit. Thus, $\mathrm{H} 2$ was rejected. 
INTERNATIONAL JOURNAL OF ACADEMIC RESEARCH IN BUSINESS AND SOCIAL SCIENCES

Vol. 10, No. 2, Feb, 2020, E-ISSN: 2222-6990 @ 2020 HRMARS

Based on the above information regression equation

would be Intention to quit $=0.953+0.743$ Workplace

bullying

Thus, the supported model of this study is as follows.

Workplace bulling $\longrightarrow$ Intention to leave

Figure 6.1 Supported Model of the study

\section{Implications of the Study Theoretical implications}

As per the theory of "The unfolding model of turnover" proposed by Lee et al., (1994) emergence of positive, negative internal, external , expected or unexpected "shock" could be the starting point of employee's turnover intentions. As they are experiencing hard situations, employees strive to reassess their working conditions. And if they identified any deviations between previously held images with existing conditions quitting expectations can be occurred. According to the results of the current study it was concluded that, due to existence of the workplace bullying creates hard situations in workplace employees' attempt to leave the organization. There by it could be concluded that "The unfolding model" developed by Lee and Mitchell (1994) can be applied in Sri Lankan context as well.

\section{Practical Implications}

These kinds of companies have to pay more attention on diminishing bullying attempts employees experienced from their superiors rather than only considering in promoting supportive organization attitudes. As sales representatives are engage in task oriented occupation, they are in the pressure of intimidating their targets. Meanwhile, work related, person related bullying attempts would demotivate them from contributing their fullest contribution for the organization. To overcome workplace bullying incidents organizations should organize counselling programs to heal the bulling victims, formulate and implement anti-bullying policies, introduce open door policy within the organization. Further, Management should take immediate actions to rectify and penalized bullies. In addition, employees who were suffering from this pain were suggested that organizations can come up with suggestions for what organizations should do to reduce turnover intention like recruit and select employees whose skills are an accurate match to the type of tasks they will be doing in their job. Next, organizations should appoint mentors and teams to work on long term projects to create better relationships among the workplace. Further would like to recommend to offer financial and non financial bonuses to retain more skilled employees who actually demonstrating commitment for their jobs and for the organization.

\section{Limitations of the Research}

The risk of response bias is a legitimate risk factor when any research is being conducted. According to Saunders et al., (2012, p.381) respondents often feel the need to provide socially desirable answers in order to avoid bringing notice to themselves. Even though this limitation is common for any 
research, researcher has developed a survey to overcome it, in which all participants responses remained completely anonymous and the survey did not request any personal information.

The next limitation is inability to conduct a longitudinal study for this research. Because the nature of this study is to demonstrate impact from one variable on another variable, it is more meaningful if the study is carried out time to time as a longitudinal study. But due to limitations in time, the researcher was restricted to a short time frame and limited resources, a longitudinal study was not feasible in this study. In addition, this study has used only data from sales representatives and used only questionnaire method and interview method to collect data, there is a probability of CMV to occur. Thus, several interventions were introduced by researcher in the design stage of this study such as different scale types, different response formats for variables to reduce common method variance as much as possible.

Furthermore, this study has collected data only from sales representatives and did not collect data from their superiors and from other influential parties such as from HR professionals in talent management, line managers and senior managers, who have capability to assess the level of bullying attempts, If done so, findings of the study would be more precise than the present.

\section{Conclusion}

Based on the current study it is identified that workplace bulling has strong positive impact on intention to quit of sales representatives in one of the leading Sales and Distribution Company in Sri Lanka. The results elaborated that even though organization are in attempting to provide a supportive culture for their employees, they would not like to retain in the company if they are bullied. Hence, these kinds of companies have to pay special attention on diminishing bulling attempts employees experienced from their superiors rather than only considering in promoting supportive organization culture.

\section{References}

Baron, R. M., \& Kenny, D. A. (1986). The moderator-mediator variable distinction in social psychological research: Conceptual, strategic, and statistical considerations. Journal of personality and social psychology, 51(6), 1173-1182

Djurkovic, N., McCormack, D., \& Casimir, G. (2008). Workplace bullying and intention to leave: the moderating effect of perceived organisational support. Human Resource Management Journal, 18(4), 405-422. https://doi.org/10.1111/j.1748-8583.2008.00081.x

Edirisinghe, P., \& De Alwis, A. C. (2015). Factors influence on employee retention in a bullied workplace: an empirical investigation in private sector organizations in Sri Lanka. Journal of Cooperate Management and Economics, 2.

Eisenberger, R., Huntington, R., Hutchison, S., \& Sowa, D. (1986). Perceived organizational support. Journal of Applied psychology, 71(3), 500-507.

Field, A. (2009). Discopering Statistics Using SPSS, Thrid Edition.

Hellgren, J., Sjoberg, A., \& Sverke, M. (1997). 57. Intention to quit: effects of job satisfaction and job percep-tions.,415-423

Hom, P. W., Griffeth, R. W., \& Sellaro, C. L. (1984). The validity of Mobley's (1977) model of employee turnover. Organizational behavior and human performance, 34(2), 141-174. 
INTERNATIONAL JOURNAL OF ACADEMIC RESEARCH IN BUSINESS AND SOCIAL SCIENCES Vol. 10, No. 2, Feb, 2020, E-ISSN: 2222-6990 @ 2020 HRMARS

Hom, P. W., Katerberg, R., \& Hulin, C. L. (1979). Comparative examination of three approaches to the prediction of turnover.Journal of Applied Psychology, 64(3), 280-290, http://dx.doi.org/10.1037/0021-9010.64.3.280

Jayasundara, J. M. A., Jayakody, J. A. S. K., Jayawardana, A. K. L. (2016). Perceived Organizational Support and Turnover Intention of Generation Y Employees: The Role of Leader-Member Exchange. Sri Lankan Journal of Management 21 (02). 1-36

Laschinger, H. K. S., \& Fida, R. (2014). New nurses' burnout and workplace wellbeing: The influence of authentic leadership and psychological capital. Burnout Research,1(1), 19-28. https://doi.org/10.1016/j.burn.2014.03.002

Laschinger, H. K. S., \& Fida, R. (2014). New nurses' burnout and workplace wellbeing: The influence of authentic leadership and psychological capital. Burnout Research, 1(1), 19-28. https://doi.org/10.1016/j.burn.2014.03.002

Lee, T. W., \& Mitchell, T. R. (1994). An alternative approach: The unfolding model of voluntary employee turnover. Academy of management review, 19(1), 51-89.

Neuman, J. H., Baron, R. A., Einarsen, S., Hoel, H., Zapf, D., \& Cooper, C. (2011). Social antecedents of bullying: A social interactionist perspective. Bullying and harassment in the workplace: Developments in theory, research, and practice, 201-225.

O'Moore, M., Seigne, E., McGuire, L., \& Smith, M. (1998). Victims of workplace bullying in Ireland. The Irish Journal of Psychology, 19(2-3), 345-357. https://doi.org/10.1080/03033910.1998.10558195

Opatha, H. H. D. N. P. (2012). Sewamandala Kalamanakaranaya.

Quine, L. (1999). Workplace bullying in NHS community trust: staff questionnaire survey. Bmj, 318(7178), 228-232.

Retrieved from

http://www.statistics.gov.lk/industry/Labour_Demand_Survey_2017_Report.pdf

Rhoades, L., \& Eisenberger, R. (2002). Perceived organizational support: a review of the literature. Journal of applied psychology, 87(4), 698-714. DOI: 10.1037//0021-9010.87.4.698

Spector, P. E. (1997). Job satisfaction: Application, assessment, causes, and consequences (Vol. 3). Sage publications.

Steel, R. P., \& Ovalle, N. K. (1984). A review and meta-analysis of research on the relationship between behavioral intentions and employee turnover. Journal of applied psychology, 69(4), 673-686, http://dx.doi.org/10.1037/0021-9010.69.4.673

Wright, P., McMahan, G., \& McWilliams, A. (1994). Human resources as a source of sustained competitive advantage: A resource-based view. International Journal of Human Resource Management, 5(2), 299-326.

Zapf, D., Einarsen, S., Hoel, H., \& Vartia, M. (2003). Empirical findings on bullying in the workplace. Bullying and emotional abuse in the workplace: International perspectives in research and practice, 103-125. 